\title{
Portal Web Anak Sekolah Minggu Sinode GMIM
}

\author{
Jofny Kevin Wonte ${ }^{1}$, Alicia A.E. Sinsuw ${ }^{2}$, Stanley D.S. Karouw ${ }^{3}$ \\ Teknik Informatika Universitas Sam Ratulangi. Manado, Jl. Kampus Unsrat Bahu, Manado 95115 \\ 11021651521@student.unsrat.ac.id', alicia.sinsuw@unsrat.ac.id², stanley.karouw@unsrat.ac.id³
}

\begin{abstract}
Abstrak - Teknologi internet yang semakin maju mulai merambat ke berbagai bidang termasuk dalam bidang kerohanian.Website merupakan salah satu kebutuhan suatu badan organisasi yang menginginkan distribusi informasi secara cepat. Komisi pelayanan anak sinode (KPAS) yang notabene merupakan organisasi pelayanan anak tertinggi di tubuh Gereja Masehi Injili Di Minahasa (GMIM) juga mengalami masalah yang sama yaitu penyampaian informasi yang kurang cepat, distribusi alat peraga yang sering terlambat, serta kreatifitas untuk menarik minat anak anak sekolah minggu melalui media yang saat ini sangat digemari. Berdasarkan latar belakang diatas penulis mencoba mengembangkan sebuah portal website untuk mengatasi masalah diatas.Dalam pengembangannya penulis menggunakan metode Rapid Aplication Development. Dengan adanya Portal Web Anak Sekolah Minggu Sinode GMIM, maka penyebaran informasi dan alat peraga dari KPAS ke jemaat jemaat akan lebih cepat, serta metode belajar firman menggunakan teknologi internet akan semakin baik.
\end{abstract}

Kata Kunci: Anak sekolah minggu, GMIM, KPAS, Portal web

\section{Pendahuluan}

Teknologi informasi semakin populer dikalangan masyarakat. Salah satu yang paling populer dari produk informasi dan telekomunikasi tersebut adalah website.Pengaruh popularitas teknologi website sendiri secara langsung mempengaruhi kehidupan masyarakat termasuk didalamnya masyarakat gerejawi. GMIM (Gereja Masehi Injili Di Minahasa) yang berpelayanan di masyarakat modern ini hendaknya menaruh perhatian terhadap perkembangan teknologi dan informasi didalamnya termasuk internet dan website karena teknologi tersebut bisa saja membawa hal negatif jika digunakan dengan cara yang salah. Internet membuat warga gereja, terutama anak-anak (kelompok umur dibawah 12 tahun) menjadi lebih leluasa mengakses kontenkonten yang tidak pantas .GMIM perlu memanfaatkan internet dan teknologi Web untuk kepentingan penyebaran Injil dan penguatan iman jemaat, terlebih anak-anak. Salah satu diantaranya dengan membuat konten - konten yang terkait pemahaman Firman dan ajaran, termasuk konten-konten yang membangun iman dan percaya jemaat, khususnya generasi yang akan datang, yakni anak sekolah minggu.

Kegiatan Ibadah sekolah minggu dalam Komisi pelayanan anak sinode GMIM pada umumnya dilaksanakan seminggu sekali. Dalam kegiatan (ibadah mengajar) tersebut seringkali proses pengajaran hanya terjadi hari itu juga tanpa bisa menjangkau kegiatan anak ketika berada di luar gereja. Belum lagi cara mengajar yang tidak kreatif sering tidak efektif dalam pembentukan karakter anak anak sekolah minggu, serta penyebaran buku Bina anak Sinode GMIM ( yang notabe nya sebagai pedoman bahan ajar guru sekolah minggu) yang memakan waktu lama. Maka itu dirasa perlu ada sebuah sistem sebagai wadah pengajaran anak sekolah minggu yang lebih efektif menarik dan bisa di akses lewat internet (website) yang sekarang ini sangat di gemari anak -anak.

Berdasarkan latar belakang di atas maka penulis ingin merancang sebuah aplikasi berbasis web yang dapat menjadi repositori alat peraga digital untuk kebutuhan pengajaran anak sekolah minggu dan sebagai media penyebaran informasi resmi dari Komisi pelayanan anak sinode GMIM.

\section{A. Rumusan masalah penelitian adalah}

- Bagaimana membangun website resmi sebagai suatu media perkenalan identitas komisi pelayanan anak sinode GMIM

- Bagaimana membangun portal web yang menjadi media penyebaran informasi resmi dari Komisi pelayanan anak sinode GMIM bagi guru dan anak sekolah minggu GMIM.

- Bagaimana membangun sebuah aplikasi website sebagai repositori bahan ajar.

\section{B. Batasan Masalah}

Batasan masalah yang ada bahwa portal web yang akan di bangun harus memiliki fitur-fitur yang berkaitan dengan:

- Penggunaan teknologi komputer berbasis web

- Penggunaan audio dan video (multimedia) sebagai bahan ajar digital

- Penggunaan text sebagai bahan ajar digital

- Pembuatan portal berita

- Pembuatan Profil dan Pengenalan Komisi Pelayanan anak sinode GMIM

- Aplikasi di khususkan untuk Kegiatan pelayanan Anak sekolah Minggu GMIM

- Bahasa pemrograman yang digunakan dalam pembangunan aplikasi adalah HTML,Javascript,CSS,PHP dan database MySQL.

\section{Tujuan Penelitian}

Tujuan dari penelitian adalah untuk membangun sebuah Portal Website untuk Komisi pelayanan anak Sinode GMIM.

D. Manfaat Penelitian

Adapun manfaat yang diharapkan adalah untuk membangun 
suatu sistem informasi yang mencakup hal - hal seperti

- Memperkenalkan Cerita Alkitab yang dipadu dengan teknologi internet kepada anak kelompok umur tertentu

- Memudahkan guru sekolah minggu mendapatkan bahan ajar, untuk mengembangkan teknik mengajar lebih efektif dan modern.

- Menjadikan multimedia sebagai alat peraga digital

- Media informasi dan berita bagi anak sekolah minggu dan guru sekolah minggu di GMIM .

D. Metodologi Penyusunan

Pada penelitian ini, Model proses yang digunakan untuk membangun aplikasi ini adalah dengan pendekatan Rapid Application Development(RAD). number of pages.

\section{LANDASAN TEORI}

\section{A. A. Gereja Masehi Injili Di Minahasa (GMIM)}

Gereja Masehi Injili di Minahasa (GMIM) adalah Sebuah gereja beraliran calvinis. Dikutip dari buku Tata Gereja GMIM 2007 dan Adendum, Bab 1 Pasal 1 "Gereja Masehi Injili di Minahasa disingkat GMIM adalah persekutuan orangorang di tanah Minahasa yang percaya kepada Yesus Kristus untuk memberitakan perbuatan-perbuatan besar Tuhan Allah dan menjadi berkat bagi orang banyak di manapun dan kapan pun."

Itu berarti GMIM Merupakan gereja yang melayani di daerah teritorial minahasa.Berdirinya GMIM di pelopori oleh dua penginjil dari Lembaga penginjilan belanda yang bernama Nederlandsch Zendeling Genootschap (NZG) Yaitu Johann Friedrich Riedel dan Johann Gottlieb Schwarz.

Dan Selama beberapa Tahun berada di bawah naungan NZG akhirnya pada tanggal 30 september 1934 GMIM menyatakan diri sebagai gereja yang mandiri dan beberapa tahun kemudian terpilihlah Dr. A. Z. R.

Wenas sebagai pemipin pribumi GMIM yang pertama.Sekarang GMIM mejadi gereja yang mepunyai sekitar kurang lebih 980 gereja lokal yang tersebar di 101 wilayah di minahasa.Pelayanan GMIM menganut sistem PresbyterianSinodal dan menganut paham Calvinis .Jadi pelayanan di bagi dalam beberapa tingkatan yaitu, tingkat sinode, tingkat wilayah dan tingkat jemaat. Pelayanan juga di kategorikan dalam kelompok usia dan status yaitu kategori pria/bapak, kategori wanita/ibu, kategori pemuda, kategori remaja, dan kategori anak yang sering disebut BIPRA (bapak/ibu/pemuda/remaja/anak) dipimpin oleh sebuah komisi. Komisi Kategorial BIPRA juga dibagi dalam tingkatan yaitu kategorial BIPRA tingkat Sinode ,BIPRA tingkat Wilayah, dan BIPRA Tingkat Jemaat dan yang akan menjadi objek penelitian adalah Komisi Pelayanan kategorial Anak Sinode GMIM [8].

\section{B. Komisi Pelayanan Anak Sinode (KPAS) GMIM dan Sekolah Minggu}

Menurut buku Adendum Tata Gereja GMIM Tahun 2007 Bab VIII Pasal 26:4; Anak-anak yang adalah anggota GMIM. Berusia sebelas tahun tiga ratus enam puluh empat hari kebawah, atau belum mengikuti kegiatan Remaja, atau duduk di Taman Kanak-Kanak dan (TK) Sekolah Dasar (SD)

Pelayanan anak sekolah minggu adalah pelayanan kerohanian agama kristen terhadap anggota jemaat yang berusia $0-12$ Tahun. Pelayan anak sekolah minggu biasa disebut guru sekolah minggu. Sedangkan organisasi yang mengatur tentang pelayanan anak sekolah minggu di GMIM dinamakan Komisi pelayanan Anak Sinode GMIM disingkat KPAS. Berikut susunan struktur organisasi komisi pelayanan anak sinode GMIM Periode tahun 2018-2022

Tabel 2.1. Komposisi KPAS

\begin{tabular}{clc}
\hline \hline No. & \multicolumn{1}{c}{ Nama } & Jabatan \\
\hline 1 & Pnt. Michael O. Mait, S.Kom & Ketua \\
2 & Pnt. Fadjar I. Sahante & Wakil Ketua \\
3 & Pnt. Syully Y. Rompis, S.Pd & Sekretaris \\
4 & Pnt. David D. Rorimpandey & Wakil Sekretaris \\
5 & Pnt. Dra. Grace H. Pontoh, M.Hum & Ass. Bendahara \\
6 & Pnt. Yamazico K.Y. Sondey & Wakil Ass. \\
& & Bendahara \\
7 & Pnt. Rudi j Roring, SE. MM & Anggota \\
8 & Pnt. James Lowing & Anggota \\
9 & Pnt. Christine Ngantung, ST, & Anggota \\
10 & Pnt. Elrinawati Lumenta,ST & Anggota \\
11 & Pnt. Ir. Jeane L. Macawalang, M.Si & Anggota \\
12 & Pnt. Peggy Pangkerego, Ams & Anggota \\
13 & Pnt. dr. Carolina A.P. Saerang & Anggota \\
14 & Pnt. Aneke Rawung, S.Pd & Anggota \\
15 & Pnt. Heentje R. Polii & Anggota \\
\hline \hline
\end{tabular}

Kegiatan pelayanan anak sekolah minggu umumnya dilakukan dengan beberapa cara, misalnya ibadah sekolah minggu pada hari minggu, ibadah pondok gembira pada hari diluar hari minggu dan beberapa kegiatan kegiatan lainya. Kegiatan kegiatan ini tujuannya adalah untuk membentuk karakter anak kearah positif dengan mengenalkan dan mengajarkan tentang alkitab dan injil [9].

Sekolah Minggu merupakan kegiatan gereja untuk menjangkau dan membawa setiap orang kepada Tuhan Yesus serta mengajarkan Alkitab untuk mengubah kehidupan mereka menjadi murid Tuhan yang penuh pengharapan (Sutanto, 2008).

Sekolah Minggu merupakan kegiatan belajar bagi anakanak yang didalamnya terdapat aktivitas belajar mengajar. Kegiatan yang dilakukan umumunya bernyanyi bersama, berdoa, membaca Alkitab dan mendengarkan cerita Alkitab yang dibawakan oleh guru sekolah minggu. Penyajian cerita biasa disertai dengan gambar-gambar yang mendukung cerita. Gambar-gambar sedianya merupakan alat peraga yang membantu anak dalam memahami akan sesuatu. (Mamangkey et al. 2013).

Sekolah minggu sama pentingnya dengan sekolah formal yang mengajarkan pengetahuan, keterampilan, dan perilaku. 
Pelajaran yang diajarkan dalam sekolah minggu termasuk di dalamnya menghafal ayat-ayat tertentu dan lagu-lagu rohani.

Peran dan fungsi sekolah minggu adalah 2 aspek yang saling berkaitan. Aspek-aspek tersebut antara lain pusat pendidikan non-formal, ujung tombak pekerjaan penginjilan, alat penjangkau dan penyalur berkat.(S.C. Riady, S. Sentinuwu, S. Karouw, dalam E-Jurnal Informatika Vol .9 tahun 2016.[13]

\section{Tentang Website}

Tentang website dikemumakan oleh Hidayat, (2010:2), merupakan suatu kumpulan halaman - halaman yang digunakan untuk menampilkan informasi teks, gambar diam atau bergerak, animasi, suara, atau gabungan dari semuanya, baik yang bersifat statis maupun dinamis yang membentuk satu rangkaian bangunan yang saling terkait, masing-masing di hubungkan dengan jaringan - jaringan halaman.Menurut Boone (Thomson), Web adalah koleksi sumber informasi kaya grafis yang saling berhubungan satu sama lain dalam internet yang lebih besar. Secara umum World Wide Web atau WWW atau juga dikenal dengan WEB adalah salah satu layanan yang didapat oleh pemakai komputer yang terhubung ke internet. Dapat disimpulkan bahwa website merupakan sebuah media elektronik yang menyajikan informasi dalam bentuk teks,suara,gambar dan video secara lebih menarik yang dapat diakses melalui aplikasi web browser (mozilla firefox, opera dan lain lain). [10]

Sementara tentang portal web Menurut Rijanto (2009) Portal web adalah situs web yang menyediakan kemampuan tertentu yang dibuat sedemikian rupa mencoba menuruti selera para pengunjungnya. Dapat disimpulkan bahwa portal website adalah sebuah situs yang menampilkan kumpulan informasi yang seragam baik dari pengelola sendiri ataupun dari sumber yang lain kedalam suatu sistem untuk mempermudah pengguna menemukan informasi - informasi yang berkaitan.[13]

\section{XAMPP dan Mysq}

Menurut website resmi XAMPP (https://www.apachefriends.org) Xampp adalah perangkat opensource yang menggabungkan tiga aplikasi kedalam satu paket,yaitu Apache,MySQL,dan PHPMyAdmin,Dengan Xampp pekerjaan anda sangat dimudahkan karena dapat menginstalasi dan mengkonfigurasi ketiga aplikasi tersebut dengan sekaligus dan otomatis. Xampp telah mengalami perkembangan dari waktu ke waktu.versi yang terbaru adalah revisi dari yang terdahulu,sehingga lebih baik dan lebih lengkap.aplikasi utama dalam paket Xampp yakni terdiri atas web server Apache,MySQL,PHP,dan PHPMyadmin.[16]

MySQL adalah sistem manajemen database yang sering digunakan bersama PHP.PHP juga mendukung pada Microsoft Access,Database Oracle,d-Base, dan sistem manajemen database lainnya. SQL \{Structured Query Language\} adalah bahasa terstruktur yang digunakan secara khusus untuk mengolah database.dan MySQL merupakan sebuah sistem manajemen database.Fransiskus Lesomar, Hans Wowor dan Virginia Tulenan menulis dalam E-journal Teknik Informatika volume 6, No. 1, (2015), bahwa Pada dasarnya MySQL adalah turunan salah satu konsep utama pada basis data yang sebelumnya sudah ada yaitu SQL (Structured Query Language). MySQL adalah sebuah implementasi dari RDBMS yang dapat digunakan secara bebas dibawah lisensi General Public License (GPL).[5]

\section{E. PHP (Hypertext Prepocesor)}

PHP merupakan bahasa berbentuk skrip yang ditempatkan dalam server dan diproses di server. Hasilnya akan dikirimkan ke client, tempat pemakai menggunakan browser. PHP dikenal sebagai sebuah bahasa scripting yang menyatu dengan tag-tag HTML, dieksekusi di server, dan digunakan untuk membuat halaman web yang dinamis seperti halnya Active Server Pages (ASP) atau Java Server Pages (JSP).PHP merupakan sebuah perangkat lunak open source (Swastika, 2006).[14]

\section{F. Multimedia}

Multimedia adalah pemanfaatan komputer untuk membuat dan menggabungkan teks, audio, gambar, bergerak (video dan animasi dengan menggunakan link dan tool yang memungkinkan pemakaian melakukan navigasi, berinteraksi, berkreasi dan berkomunikasi. (Feiby Marlin Pongoh, Alicia A. E. Sinsuw, Virginia Tulenan, dalam E-Journal Teknik Informatika Vol.8, No.1 .2016) [4].

\section{Metodologi Penelitian}

Metode Penilitian menggunakan kerangka berpikir seperti pada gambar dibawah ini:

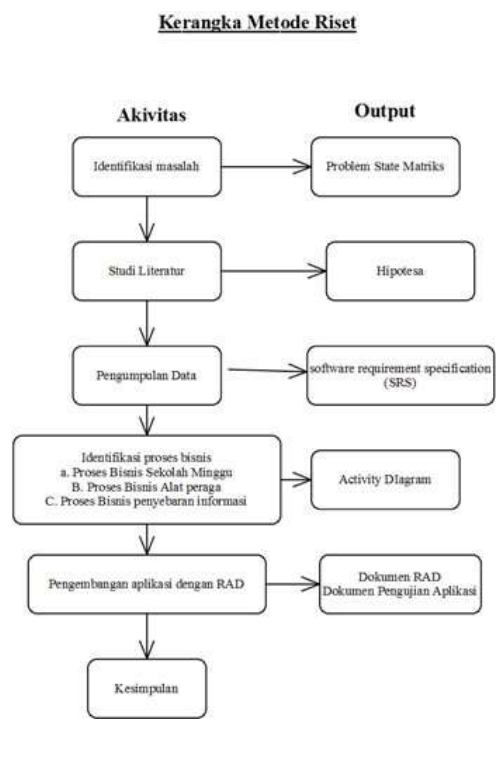

Gambar 3.1. Kerangka Metode Riset

\section{A. Identifikasi Masalah}

Masalah pada komisi pelayanan anak di identifikasi dengan 
menggunakan problem state matriks seperti dalam tabel berikut ini:

Tabel 3.1. Problem State Matriks KPAS

\begin{tabular}{|c|c|c|}
\hline & Masalah & "Solusi yang diusulkan \\
\hline 1. & \begin{tabular}{llr} 
Perlunya & \multicolumn{2}{r}{ penyampaian } \\
informasi & secara cepat dari \\
KPAS kepada & Komisi \\
Pelayanan anak jemaat
\end{tabular} & $\begin{array}{l}\text { Mengganti atau menambahkan } \\
\text { metode penyebaran informasi } \\
\text { yang konvensional ( dengan } \\
\text { Surat cetak) dengan metode } \\
\text { lain yang lebih efektif }\end{array}$ \\
\hline 2. & $\begin{array}{l}\text { Identitas KPAS belum begitu } \\
\text { dikenal oleh anggota, apalagi } \\
\text { oleh dunia luar }\end{array}$ & $\begin{array}{l}\text { Membuat sebuah wadah untuk } \\
\text { memperkenalkan diri } \\
\text { sehingga masyarakat dengan } \\
\text { mudah bisa mengenal }\end{array}$ \\
\hline 3. & $\begin{array}{llr}\text { Keterbatasan alat peraga dan } \\
\text { sumber daya untuk } \\
\text { membuat/mengguakan alat } \\
\text { peraga }\end{array}$ & $\begin{array}{l}\text { Membuat alat peraga yang } \\
\text { gampang dipelajari, dan tidak } \\
\text { susah untuk di gunakan }\end{array}$ \\
\hline 4. & $\begin{array}{l}\text { Perlu ada kreativitas baru yang } \\
\text { sesuai dengan perkembangan } \\
\text { zaman untuk menarik minat } \\
\text { anak - anak terhadap cerita } \\
\text { alkitab }\end{array}$ & $\begin{array}{l}\text { Memanfaatkan teknologi yang } \\
\text { notabene sangat menarik untuk } \\
\text { anak - anak. }\end{array}$ \\
\hline
\end{tabular}

\section{B. Pengumpulan data}

Pengumpulan data menggunakan beberapa metode yaitu kuesioner, studi literatur dan analisa menggunakan software requirement specification.

Pernyataan dan pertanyaan pada kuesioner memuat 3 sudut padang yaitu sudut pandang guru sekolah minggu, sudut pandang anak sekolah minggu berdasarkan pengamatan guru sekolah minggu, dan sudut pandang masyarakat umum. Pada hasil akhir tersimpulkan bahwa masalah pada tiga sudut pandang itu bisa di tunjang dengan teknologi web.

Studi literatur dengan menggali informasi dari beberapa buku, jurnal kutipan -kutipan dan informasi lain. Setelah membaca hasil riset dari Julita Mamangkey, Alicia Sinsuw, Stanley Karouw , Nancy Tuturoong,Tentang Aplikasi EVisual aid berbasi android (2013), maka dapat disimpulkan bahwa teknologi dapat membantu perkembangan alat peraga untuk anak sekolah minggu. Penulis juga mencoba menggali informasi dari buku Rekayasa Web karya Janner Simamarta (2010), dijelaskan bahwa interaksi manusia dan komputer yang baik dapat memunculkan suatu penyelesaian masalah yang efektif guna menanggulangi keterbatasan manusia dalam berbagai hal.

Software requirement specification sebagai kesimpulan dari bagian pengumpulan data untuk mengakomodir kebutuhan sistem agar bisa menentukan sistem seperti apa yang akan dibuat.

Tabel 3.2. Software Requirement Spesification Portal Web KPAS

\begin{tabular}{|c|c|}
\hline Kebutuhan Fungsional & Kebutuhan Non Functional \\
\hline $\begin{array}{llr}\text { 1. } & \text { Perangkat } & \text { lunak } \\
\text { mempunyai tombol } & \text { login } \\
\text { untuk keamanan } & \end{array}$ & $\begin{array}{l}\text { 1. } \\
\text { Perangkat lunak } \\
\text { mudah dipelajari dan } \\
\text { digunakan. }\end{array}$ \\
\hline
\end{tabular}

\begin{tabular}{|c|c|c|c|}
\hline 2. & $\begin{array}{l}\text { Perangkat lunak mampu } \\
\text { mengelola multimedia } \\
\text { (text,video, gambar, suara) } \\
\text { Perangkat lunak mampu } \\
\text { terkoneksi ke perangkat } \\
\text { user melalui internet }\end{array}$ & 2. & $\begin{array}{l}\text { Sistem membutuhkan } \\
\text { Perangkat komputer } \\
\text { standar atupun gadget } \\
\text { Sistem membutuhkan } \\
\text { koneksi internet } \\
\text { Sistem dapat } \\
\text { digunakan oleh semua } \\
\text { kelompok umur }\end{array}$ \\
\hline \multicolumn{2}{|c|}{ Kebutuhan Data } & \multicolumn{2}{|c|}{ Kebutuhan Keamanan } \\
\hline 1. & $\begin{array}{lll}\begin{array}{l}\text { Sistem } \\
\text { database }\end{array} & \text { harus memiliki }\end{array}$ & 1. & $\begin{array}{l}\text { Administrator } \\
\text { mempunyai passcode } \\
\text { login }\end{array}$ \\
\hline
\end{tabular}

\section{Identifikasi Proses Bisnis}

Proses bisnis adalah suatu kumpulan dari aktivitas atau pekerjaan terstruktur yang saling berhubungan untuk menyelesaikan suatu masalah tertentu atau yang menghasilkan suatu keluaran (produk/output) atau layanan (demi meraih tujuan tertentu) dan mendukung pencapaian tujuan serta sasaran strategis dari suatu organisasi. Maka Identifikasi proses bisnis sangat diperlukan untuk memahami seperti apa alur pekerjaan yang terjadi pada suatu sistem.

.Proses bisnis untuk menggambarkan aktifitas apa yang terjadi pada Komisi pelayanan anak dan kegiatanya. Disimpulkan tiga proses bisnis yaitu, proses bisnis ibadah sekolah minggu, proses bisnis penyebaran informasi,proses bisnis distribusinalat peraga

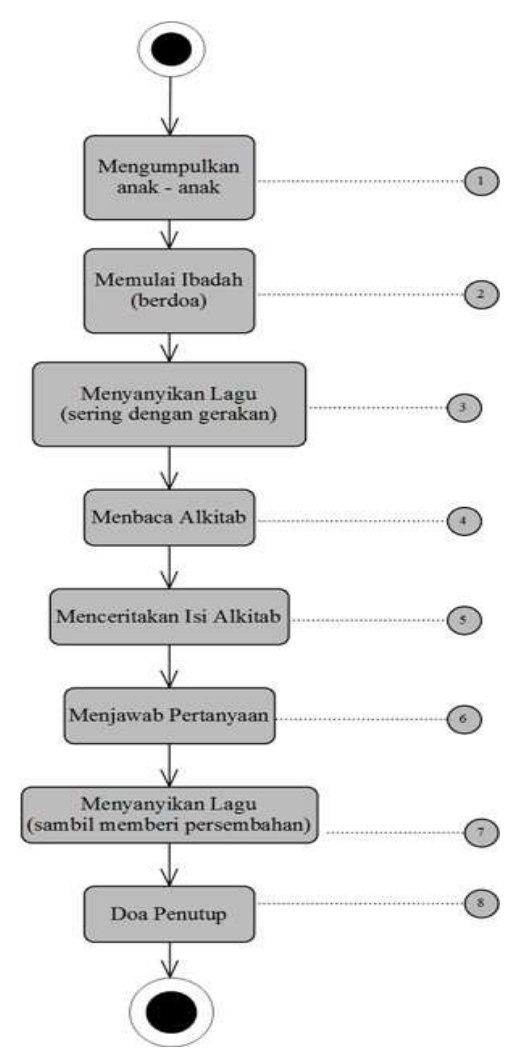

Gambar 3.2. Proses Bisnis Ibadah Sekolah Minggu 


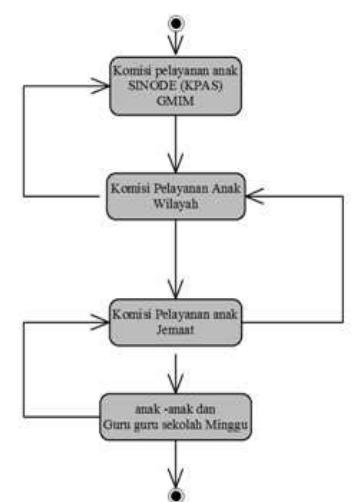

Gambar 3.3. Proses Bisnis alur penyebaran informasi

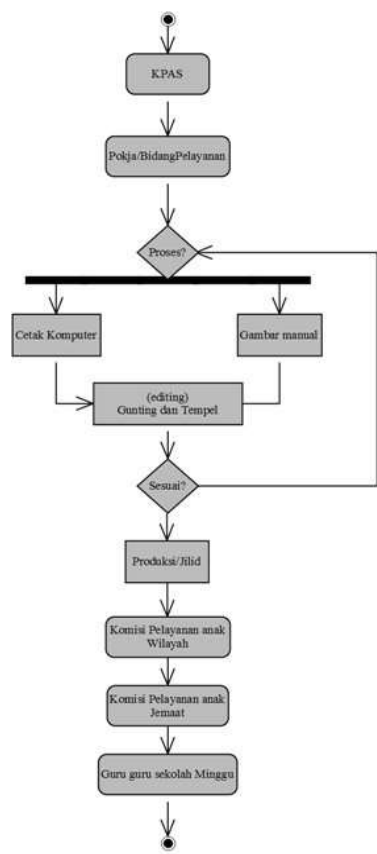

Gambar 3.4. Proses Bisnis distribusi alat peraga

Pada gambar 3.2. menjelaskan tentang tata cara ibadah sekolah minggu pda umumnya. Ibadah sekolah minggu sudah ada sejak GMIM berdiri. Aktivitas dalam ibadah pun masih sama yaitu dimulai dengan mengumpulkan anak-anak, memulai ibadah (doa), menyanyikan lagu dengan gerakan, membaca alkitab, mendengarkan/menceritakan isis alkitab, menjawab pertanyaan, memberi persembahan, dan penutup.

Gambar 3.3. menjelaskan tentang alur penyebaran informasi dari KPAS ke jemaat-jemaat. Komisi pelayanan anak sinode (KPAS) GMIM , harus menyebarkan informasi kepada seluruh anggotanya adapun langkah -langkah yang biasanya dilakukan adalah dengan mencetak surat resmi dan di distribusikan secara manual. Informasi dari KPAS secara resmi harus turun dulu ke komisi wilayah, setelah itu tugas dari komisi wilayah membagikannya kepada komisi anak jemaat, dan selanjutnya dari komisi anak jemaat kepada guruguru sekolah minggu jemaat, begitupun untuk alur informasi sebaliknya

Gambar 3.4. menjelaskan tentang tatacara pembuatan dan distribusi alat peraga. Alat peraga adalah alat bantu yang memudahkan penyampaian cerita alkitab kepada anak anak. Tujuannya adalah supaya anak -anak yang masih susah di ajar dengan kata-kata dapat melihat gambar-gambar dan dapat lebih mudah mengerti. Tujuan dari alat peraga juga adalah untuk membuat proses penyampaian cerita lebih menarik. Adapun proses pembuatanya melibatkan KPAS dan tim Pokja. POKJA adalah tim Bidang pelayanan yang mengurusu pembuatan alat peraga sesuai dengan kurikulum dari KPAS dan akan disebarkan kepada jemaat -jemaat.

Dari ketiga aktivitas yang digambarkan oleh proses bisnis tersebut ,didapati bahwa masih bisa di optimalkan dengan bantuan sistem(portal) yang akan dibangun.

\section{Rapid aplication Development (RAD)}

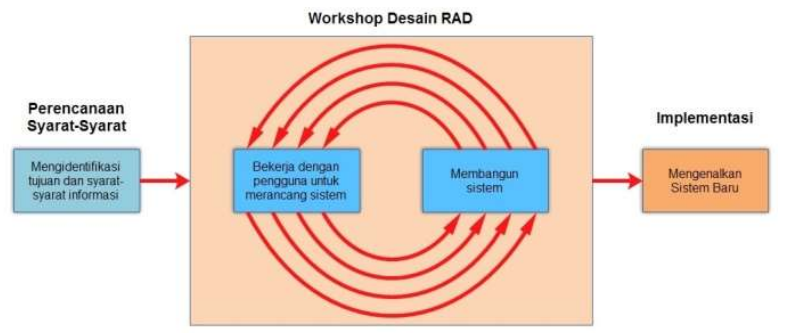

Gambar 3.5. alur kerja Rapid Aplication Development

Rapid Aplication Development terdiri dari tiga aktivitas yaitu

1. Analisa persyaratan

2. RAD Desain Workshop

a. Analisa Pemodelan

b. Desain Modeling

3. Implementasi / Konstruksi

1. Analisa persyaratan

Tahap analisis persyaratan bertujuan untuk mengidentifikasi kebutuhan, batasan dan objektifitas dari sistem yang akan dibangun ,dengan cara mengumpulkan data dari stakeholderSehinggaaplikasi yang akan dibuat akan sesuai dengan yang dibutuhkan oleh pengguna. Pada bagian inimenggunakan tools UML. Pada fase ini terdiri atas4 aktivitas yang akan dikerjakan yaitu, komunikasi dan perencanaan, Studi kelayakan, Spesifikasi pengguna dan Spesifikasi sistem.

Studi kelayakan dibagi dalam beberapa bagian yaitu studi pustaka, studi lapangan, dan studi kelayakan ekonomis. Studi pustaka adalah dengan membaca hasil -hasil riset, buku buku dan literatur yang berkaitan. Studi lapangan adalah dengan observasi atau pengamatan dilapangan terkait dengan objek penelitian. Sedangkan studi kelayakan ekonomis adalah membandingkan sistem secara ekonomi baik secara tangible dan intangible dan berdasarkan hasil tabel cost-benefit analysis yang di kutip dari jurnal informatika dengan judul Pengembangan Portal Anak Sekolah Minggu Sebagai Bagian dari system informasi terpadu Gereja Masehi Injili Di Minahasa (Stanley Karouw, Benny Narasiang, 2016) . 


\section{Studi Kelayakan Ekonomis}

Studi kelayakan ekonomi menyangkut keuntungan dan kekuragan aplikasi secara ekonomi.

a. Persyaratan Bisnis:

(1). Portal website yang dibangun dapat menampilkan informasi secara cepat,(2) Portal website mudah digunakan ,(3) Portal website bisa menjadi repositori bahan ajar ,(4)Alat peraga dalam website menarik dan interaktif, sesuai dengan bahan ajar dari sinode,(5). Alat peraga yang dihasilkan dapat mendorong kreativitas anak, dan meningkatkan pemahaman anak (6). Alat peraga yang dihasilkan harus murah dan mudah untuk didistribusikan.

b. Business Value:

Tangible;(1)Mengurangi biaya pencetakan surat menyurat,(2) Mengurangi biaya transport distribusi surat,(3)Mengurangi biaya pembuatan alat peraga manual,(4)Mengurangi biaya pelatihan penggunaan alat peraga manual,(5)Menghemat waktu guru dalam memberikan pemahaman kepada anakanak.

Intangible:(1) Meningkatkan pelayanan anak sekolah minggu,(2) Efisiensi waktu penyebaran informasi,(3)Melatih anak anak dan guru guru sekolah minggu menggunakan teknlogi,(4) Meningkatkanantusiasme anaktentang Cerita Alkitab,(5) Merangsang daya kreativitas anak

c. Tabel Cost-Benefit

Tabel 3.3. cost-benefit analysis [12]

\begin{tabular}{|c|c|c|c|c|}
\hline & 2016 & 2017 & 2018 & Total \\
\hline $\begin{array}{l}\text { Mengurangi } \\
\text { biaya } \\
\text { pembuatan } \\
\text { alat peraga }\end{array}$ & 1.835 .000 & 1.835 .000 & 1.835 .000 & \\
\hline $\begin{array}{l}\text { Mengurangi } \\
\text { biaya } \\
\text { fotocopy }\end{array}$ & 720.000 & 720.000 & 720.000 & \\
\hline $\begin{array}{l}\text { Total } \\
\text { Benefit: }\end{array}$ & 2.555 .000 & 2.555 .00 & 2.555 .00 & \\
\hline $\begin{array}{l}\text { PV of } \\
\text { Benefits: }\end{array}$ & $238.785,046$ & $238.785,046$ & $\begin{array}{l}238.785,04 \\
6\end{array}$ & $\begin{array}{l}716.355,13 \\
8\end{array}$ \\
\hline $\begin{array}{l}\text { Software } \\
\text { Licenses }\end{array}$ & 0 & 0 & 0 & \\
\hline $\begin{array}{l}\text { Server } \\
\text { software }\end{array}$ & 0 & 0 & 0 & \\
\hline $\begin{array}{l}\text { Developmen } \\
\text { t Labor }\end{array}$ & 270.000 & 0 & 0 & \\
\hline Total & & & & \\
\hline $\begin{array}{l}\text { Developmen } \\
\text { t Costs }\end{array}$ & 270.000 & 0 & 0 & \\
\hline Hardware & 0 & 0 & 0 & \\
\hline Software & 0 & 0 & 0 & \\
\hline
\end{tabular}

\begin{tabular}{|c|c|c|c|c|}
\hline $\begin{array}{l}\text { Operational } \\
\text { Labor }\end{array}$ & 400.000 & 510.000 & \multicolumn{2}{|l|}{615.000} \\
\hline \multicolumn{5}{|l|}{ Total } \\
\hline Operational & 400.000 & 510.000 & \multicolumn{2}{|l|}{615.000} \\
\hline \multicolumn{5}{|l|}{ Costs } \\
\hline Total Cost & 1.070 .000 & 1.020 .000 & 1.230 .000 & \\
\hline PV of Costs & $345.794,39$ & $102.803,74$ & $107.476,63$ & $556.074,76$ \\
\hline $\begin{array}{l}\text { PV of All } \\
\text { Costs }\end{array}$ & $345.794,39$ & $448.598,13$ & $556.074,76$ & \\
\hline \multicolumn{5}{|l|}{ Total Project } \\
\hline Benefits- & (114.500) & 145.500 & 140.500 & \\
\hline \multicolumn{5}{|l|}{ Costs } \\
\hline Yearly NPV & $\begin{array}{l}(107.009,344 \\
)\end{array}$ & $28.971,962$ & $\begin{array}{l}160.280,37 \\
8\end{array}$ & $82.242,996$ \\
\hline Cumulative & $(107.009,344$ & $(78.037,382$ & \multirow{2}{*}{\multicolumn{2}{|c|}{$82.242,996$}} \\
\hline NPV & ） & ) & & \\
\hline $\begin{array}{l}\text { Return on } \\
\text { Investment }\end{array}$ & \multicolumn{4}{|c|}{$14.78 \%(82.242,996 / 556.074,76)$} \\
\hline Break-Even & \multirow{2}{*}{\multicolumn{4}{|c|}{$\begin{array}{l}2.48 \text { years (break-even occurs in year } 3 \text {; }([160.280,378- \\
82.242,996] / 160.280,378)\end{array}$}} \\
\hline Point & & & & \\
\hline
\end{tabular}

Keterangan:

- PV of All Benefits: Keuntungan yang diperoleh.

- Development Labor: Biaya yang diperoleh pengembang dalam pengembangan sistem informasi ini.

- Total Operational Cost: Biaya operasional penggunaan program setiap tahun

- PV of All Cost: Seluruh biaya yang dikeluarkan setiap tahun.

- Total Project Benefit-Cost: Biaya pendapatan dikurangi dengan biaya operasional.

- Yearly NPV: Menunjukan biaya keuntungan dimasa sekarang dikurangi biaya masa sekarang dan dihitung pertahun.

- Comulative NPV: Jumlah NPV yang ditambahkan setiap tahun.

- Return On Investment: Berapa presentasi pengembalian biaya yang di peroleh dari investasi yang diberikan.

- Break Even Point: Pada tahun berapakah modal yang dikeluarkan akan kembali.

Pada jurnal yang sama juga mengemukakan daftar resiko seperti pada tabel dibawah ini:

Tabel 3.5. Daftar Resiko [12]

\begin{tabular}{|c|c|}
\hline Risk\#1 & Feature Creep \\
\hline Likehood of Risk & $\begin{array}{l}\text { Tinggi (high probability of } \\
\text { risk) }\end{array}$ \\
\hline $\begin{array}{l}\text { Potential impact on the } \\
\text { project }\end{array}$ & $\begin{array}{l}\text { Bertambahnya fitur yang } \\
\text { harus dikerjakan tim }\end{array}$ \\
\hline Ways to address this risk & $\begin{array}{l}\text { Finalisasi fitur aplikasi pada } \\
\text { dokumen tertulis;Melakukan } \\
\text { dokumentasi manajemen } \\
\text { perubahan }\end{array}$ \\
\hline
\end{tabular}

2. RAD Desain Workshop

a. Analisa Pemodelan

Analisis pemodelan bertujuan untuk menganalisis sistem yang sedang berjalan dari semua kegiatan yang terjadi pada sistem. Menggunakan 2 UML yaitu use case diagram dan 
activity diagram. Dan terdapat beberapa aktivitas yang digambarkan dalam skema.

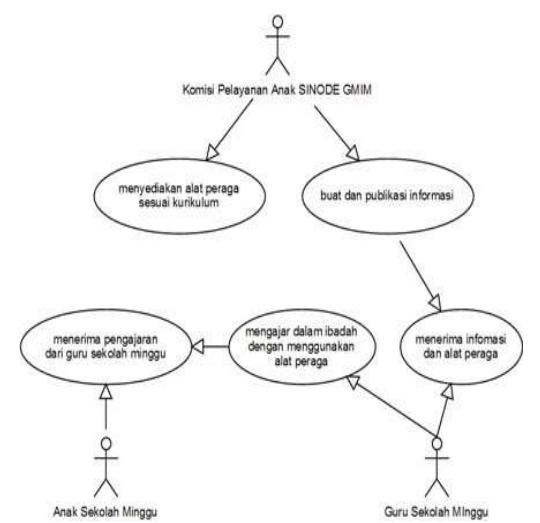

Gambar 3.6. skema identifikasi pelaku menurut sistem

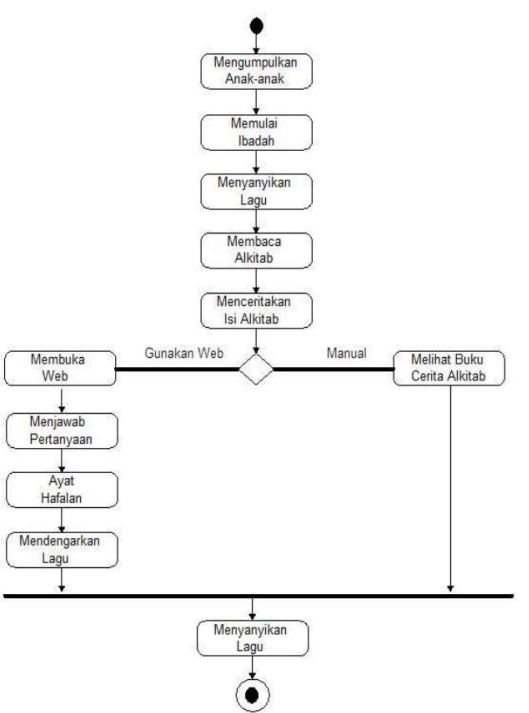

Gambar 3.7. Proses sekolah minggu yang direncanakan[12]

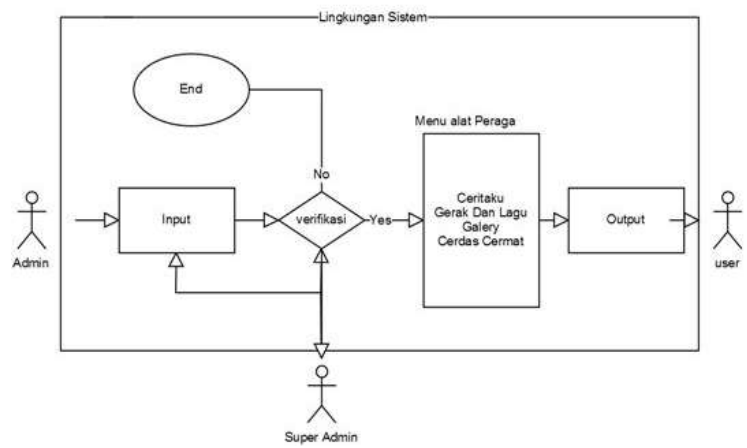

Gambar 3.8. Proses unggah dan unduh alat peraga melalui sistem

Gambar 3.6. Menunjukan aktivitas para aktor (pelaku) dalam organisasi Komisi Pelayanan Anak dari Sinode kepada guru-guru dan anak anak di jemaat. Dimodelkan dalam skema terdapat 3 aktor yaitu komisi pelayanan anak, guru sekolah minggu dan anak sekolah minggu.

Komisi bertanggung jawab atas pembuatan informasi dan kurikulum serta alat peraga dan bahan ajar kepada guru sekolah minggu. Guru sekolah minggu menerima informasi menjalankannya dan mengajar anak sekolah minggu sesuai dengan kurikulum dan bahan ajar yang di sediakan anak sekolah minggu. Sesuai dengan gambaran di atas maka sistem yang akan di bangun harus mengakomodir ketiga aktor ini. Maksud dari proses ini adalah untuk menentukan level akses pada siste yang akan di bangun nantinya digolongkan sesuai dengan hak dan kewajiban dalam organisasi.

Gambar 3.7. adalah bagian pengembangan dari gambar 3.2.yaitu menjadikan sekolah minggu semakin efektif dengan membuat alat peraga berbentuk digital. Alurnya adalah sebagai berikut. Guru sekolah minggu mengumpulkan anakanak untuk beribadah, memulai ibadah, menyanyikan lagu bisa menggunakan fitur gerak dan lagu pada web, membaca alkitab, menceritakan isi alkitab dapat menggunakan dua metode yaitu dengan buku cerita manual (fisik) atau bisa dengan membuka buku elektronik pada website dengan menggunakan gadget yang ada. Setelah itu anak-anak diarahkan menjawab pertanyaan dan ayat hafalan, mendengarkan lagu dan menyanyikannya.[12]

Gambar 3.8. Menggambarkan alur unduh dan unggah alat peraga digital melalui sistem. Dapat dilihat bahwa sistem mempunyai tingkat akses yang lebih tinggi dari admin (superadmin) tujuannya adalah untuk proses verifikasi apakah konten yang di upload oleh admin layak atau sesuai dengan maksud dari KPAS. Superadmin berhak menerima atau menolak konten yang di upload disistem.

\section{HASIL DAN PEMBAHASAN}

\section{A. Desain Modeling}

Tahap ini di bangun untuk memodelkan interaksi sistem dan membangun rancancangan antarmuka. Interaksi sistem digambarkan dengan menggunakan model activity diagram seperti dibawah ini.

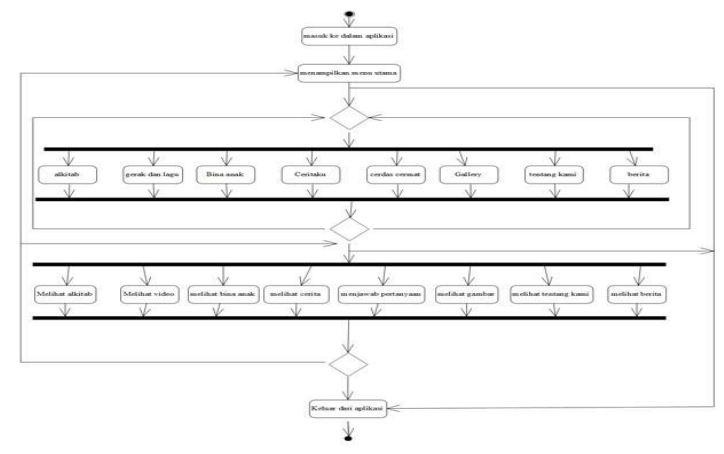

Gambar 4.1. Activity Diagram portal web yang akan dibangun

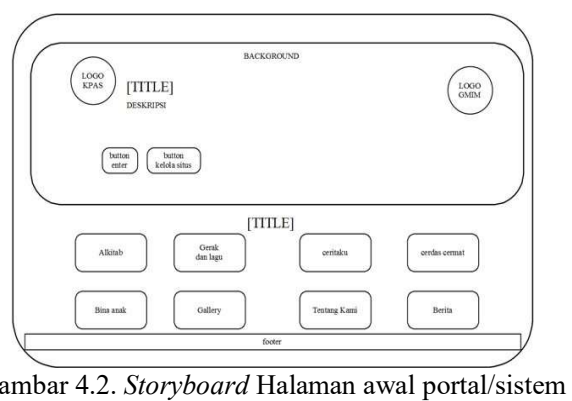



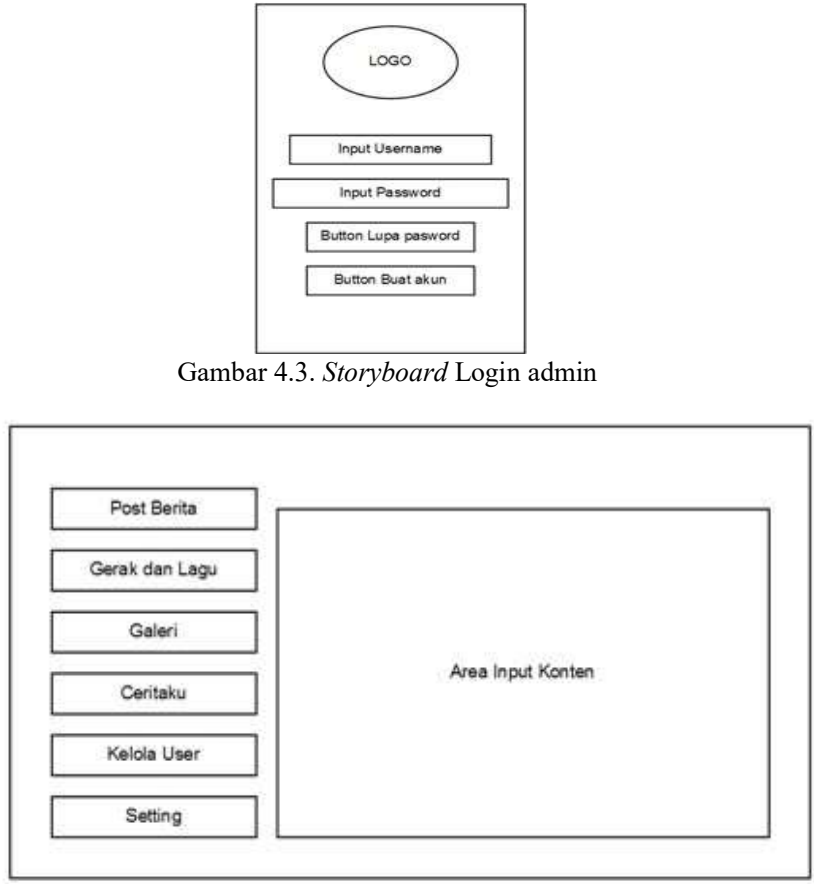

Gambar 4.4. Storyboard menu admin

Gambar 4.2. adalah storyboard halaman awal yang menampilkan seluruh menu atau fitur-fitur pada sistem. Dapat dilihat pada storyboard di atas bahwa website yang akan di bangun memiliki 10 button, yaitu button masuk, kelola situ, alkitab, gerak dan lagu, ceritaku,cerdas cermat,bina anak,gallery, tentang kami dan berita

Gambar 4.3. Dan berikut storyboard untuk halaman input login, halaman proses input konten. Untuk menu login kelola berita adalah seperti gambar diatas, user harus memasukan nama user, dan memasukan password. Jika password salah akan keluar textbox menyatakan password salah, dan jika password benar akan langsung dialihkan pada halaman admin.

Gambar 4.4. adalah tampilan menu admin. Menu pada admin adalah untuk mengelola konten dari fitur-fitur yang akan ditampilkan pada sistem.

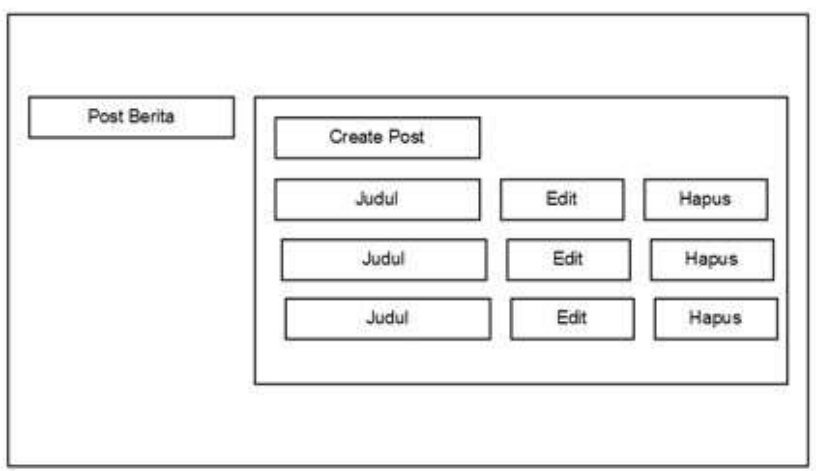

Gambar 4.5. Storyboard menu admin kelola berita

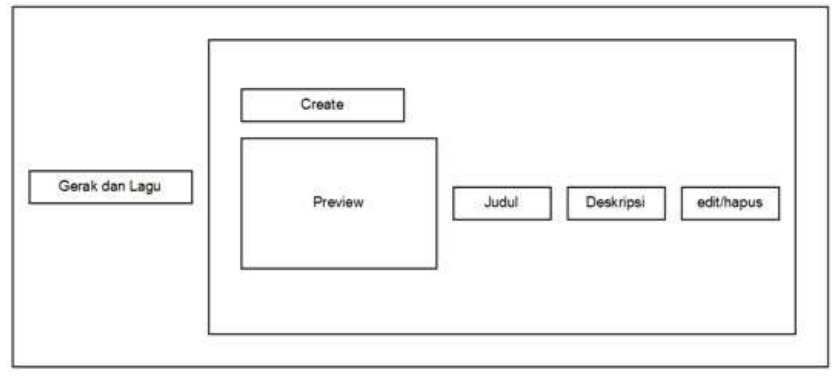

Gambar 4.6. Storyboard menu admin kelola gerak dan lagu

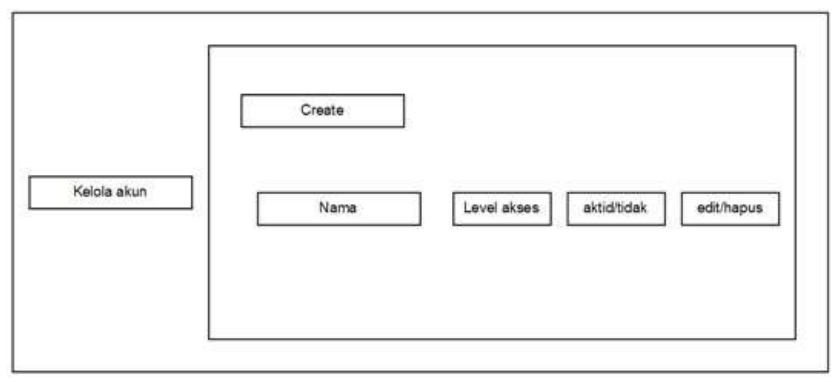

Gambar 4.7. Storyboard menu superadmin kelola akun

Gambar 4.5. adalah Storyboard kelola berita dan gambar 4.6 adalah storyboard kelola gerak dan lagu. Menu kelola ini dapat diakses oleh admin sedangkan untuk verifikasi tampilkan disistem diakses oleh superadmin.

Gambar 4.7 adalah storyboard kelola akun yang membedakan hak akses admin dan superadmin. Disini superadmin dapat mengelola akun -akun yang terdaftar sebagai admin, memberikan hak akses serta menambahka atau menghapus akun.

\section{B. Implementasi/Kontruksi}

Setelah tahap desain modeling sudah di lakukan maka sistem siap untuk masuk ke tahap konstruksi / implementasi. Pada tahap ini akan di lakukan beberapa tahap yaitu implementasi kode sumber (coding), implementasi basis data (database) dan testing (hosting).

Banyak orang menganggap coding sebagai pemrograman, padahal coding merupakan salah satu dari langkah-langkah pemrograman.Coding adalah menerjemahkan persyaratan logika dari pseudocode atau diagram alur ke dalam suatu bahasa pemrograman baik huruf, angka, dan simbol yang membentuk program. Dalam aktivitas kali ini digunakan beberapa tools sebagai alat bantu sesuai dengan kebutuhan dari sistem, misalnya untuk pembuatan antarmuka menggunakan tool Adobe fireworks dan adobe dreamweaver serta untuk penerapan kode menggunakan tools notepad++, sedangkan untuk bahasa pemrograman menggunakan bahasa pemrograman HTML dan PHP. Dan berdasarkan fitur -fitur sistem yang akan dibangun kode sumber di buat sesuai dengan fitur-fitur tersebut. 
Tabel 4.1. Daftar Kode Sumber yang dibuat

\begin{tabular}{|c|c|c|}
\hline No & Nama Halaman & $\begin{array}{l}\text { Nama kode } \\
\text { Sumber }\end{array}$ \\
\hline 1 & Homepage & Index.php \\
\hline 2 & Kelola situs & login.php \\
\hline 3 & Gerak dan Lagu & Video.php \\
\hline 4 & CeritaKu & Index.html \\
\hline 5 & Cerdas Cermat & Index.html \\
\hline 6 & Bina Anak & Index.html \\
\hline 7 & Gallery & galery.php \\
\hline 8 & Tentang kami & $\begin{array}{c}\text { Tentang } \\
\text { kami.php }\end{array}$ \\
\hline 9 & Berita & Home.php \\
\hline
\end{tabular}

Setelah itu dilakukan implementasi basis data .Sesuai dengan kebutuhan sistem maka di perlukan basis data sebagai tempat unutk menampung data ataupun konten yang diperlukan. Perancangan atribut dan tabel pada database di sesuaikan dengan kebutuhan sistem. Adapun database yang di gunakan adalah DBMs MySql dan data base yang di gunakan bernama kpas_sql.sql berikut daftar tabelnya dan relasinya .

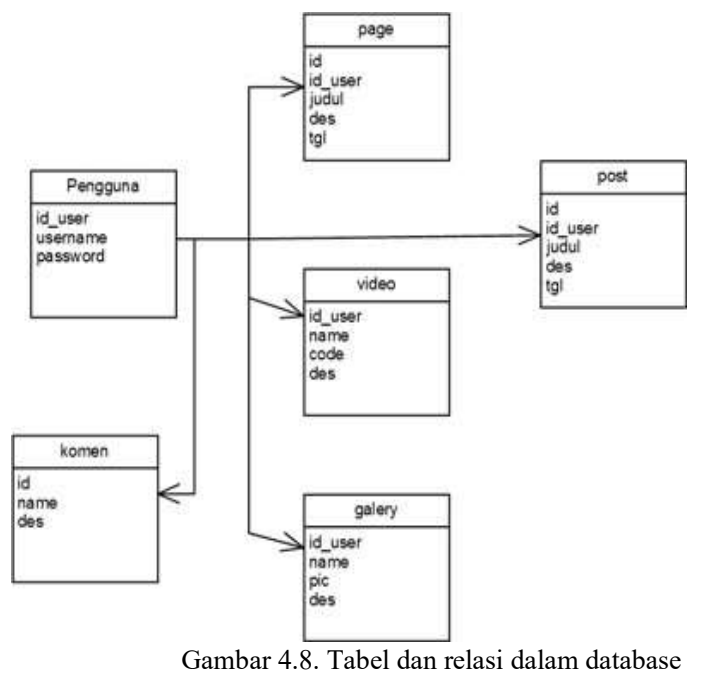

Sesuai hasil analisa sistem, maka sistem berhasi dibangun untuk memenuhi beberapa permasalahan seperti yang dijelaskan pada bagia pendahuluan. Adapun hasi pemodelan antarmuka yang telah di rancang pada bagian sebelumya adalah sebagai berikut.

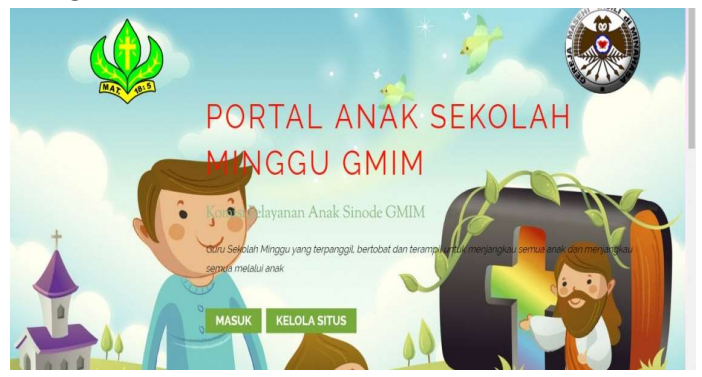

Gambar 4.9. Halaman awal sistem
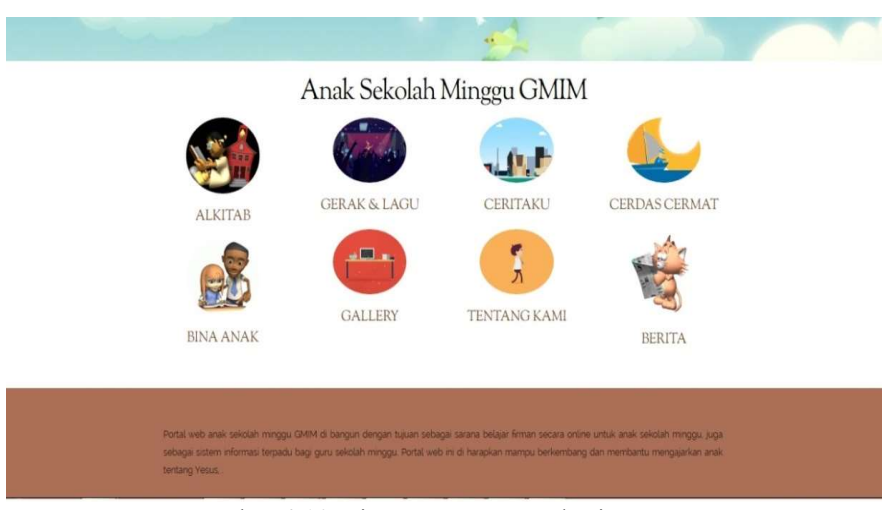

Gambar 4.10. Fitur atau menu pada sistem

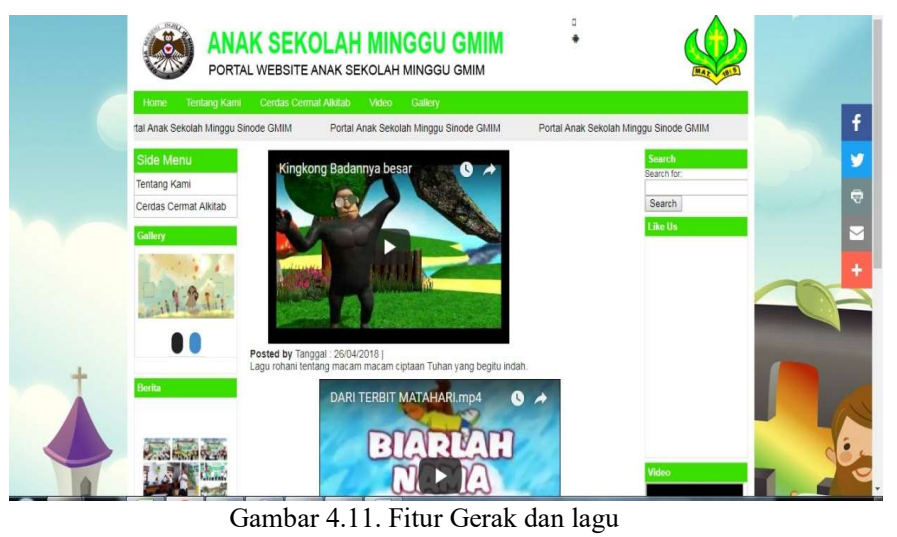

Gambar 4.9 adalah tampilan awal sistem .Pada halaman ini terdapat logo Komisi pelayanan anak sinode GMIM, Logo GMIM yang di link ke website resmi GMIM, Informasi nama sistem, Nama organisasi dan deskripsi, serta terdapat dua button yaitu Masuk dan Kelola Situs. Jika pengguna memilih Button masuk maka pengguna akan di arah kepada menu menu dibawahnya ,dan untuk masuk mode admin/superadmin harus memilih button Kelola situs.

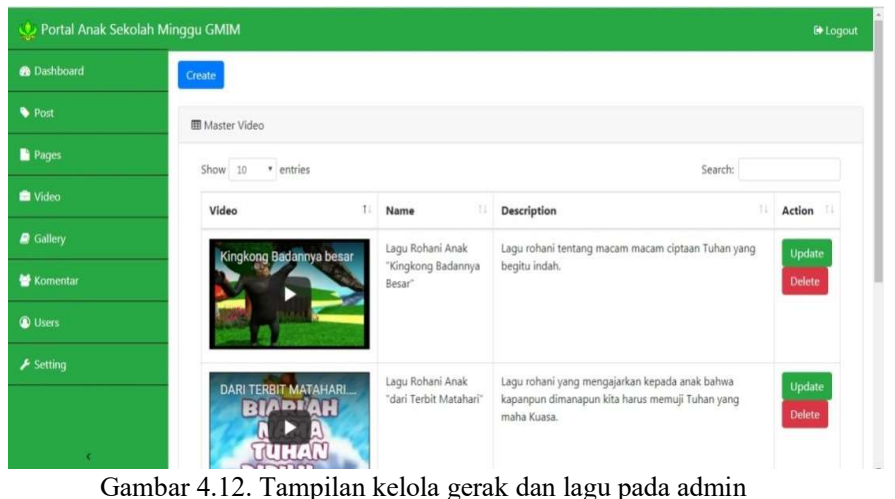

Gambar 4.12. Tampilan kelola gerak dan lagu pada admin 


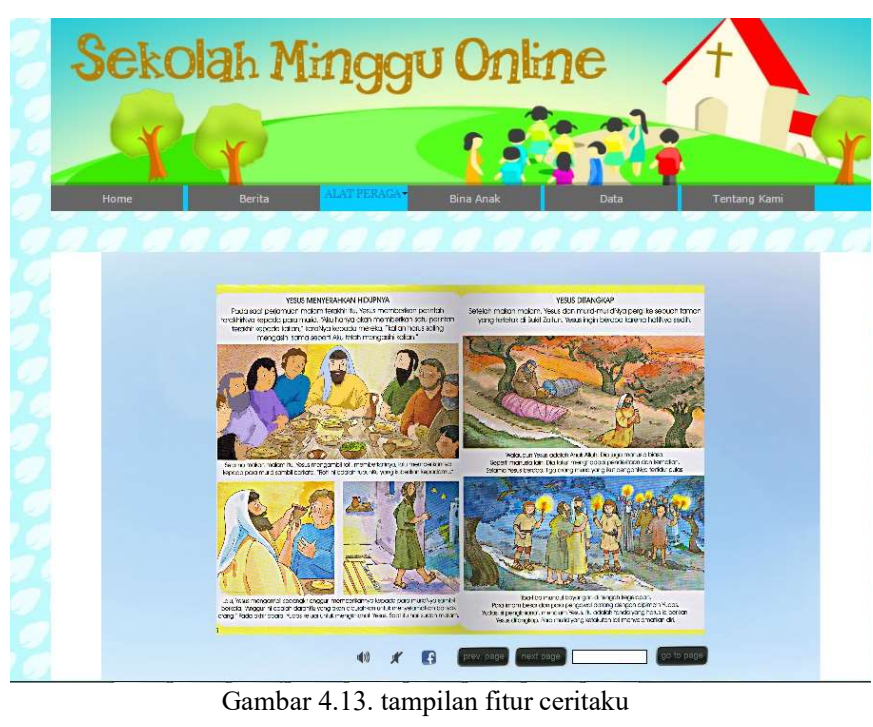

Gambar 4.10 adalah tampilan fitur fitur yang di tawarkan. Ada 8 fitur yang di tawarkan, masing masing sesuai dengan kegunaanya yaitu alkitb,gerak dan lagu,ceritaku,cerdas cermat,bina anak,gallery,tentang kami dan berita. Untuk Alkitab tidak akan dibahas karena tidak ada program alkitab online yang sudah di bangun untuk anak anak.

Gambar 4.11. adalah tampilan fitur gerak dan lagu. Gerak dan lagu adalah halaman yang berfungsi menampilkan video dan musik yang di gunakan segabai media alat peraga. Maksudnya adalah video yang ditampilkan adalah video tentang lagu - lagu anak sekolah minggu, video menyayi dan menari bahkan juga bisa untuk khotbah. Fitur gerak dan lagu ini memanfaatkan sistem embed code dengan mengambil kode video pada portal portal video (contohnya http://www.youtube.com/) dan menampilkannya di sistem. Tujuannya adalah untuk menghemat ruang penyimpanan server. Sedangkan gambar 4.12. adalah tampilan kelola gerak dan lagu pada mode admin.

Gambar 4.13. adalah tampilan fitur ceritaku. Fitur ini bertujuan menampilkan buku cerita untuk anak - anak.Buku cerita yang di tampilkan adalah buku cerita elektronik .Buku elektronik ini berjudul telur paskah karya tim mahasiswa dari sebuah universitas dimanado. Untuk memindahkan halaman dapat menggunakan kursos (mouse) ataupun dengan menggunakan tombol arah pada keyboard.

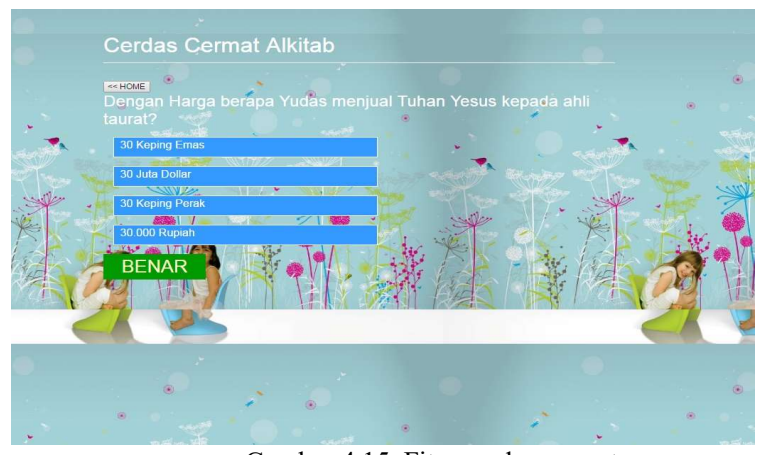

Gambar 4.15. Fitur cerdas cermat

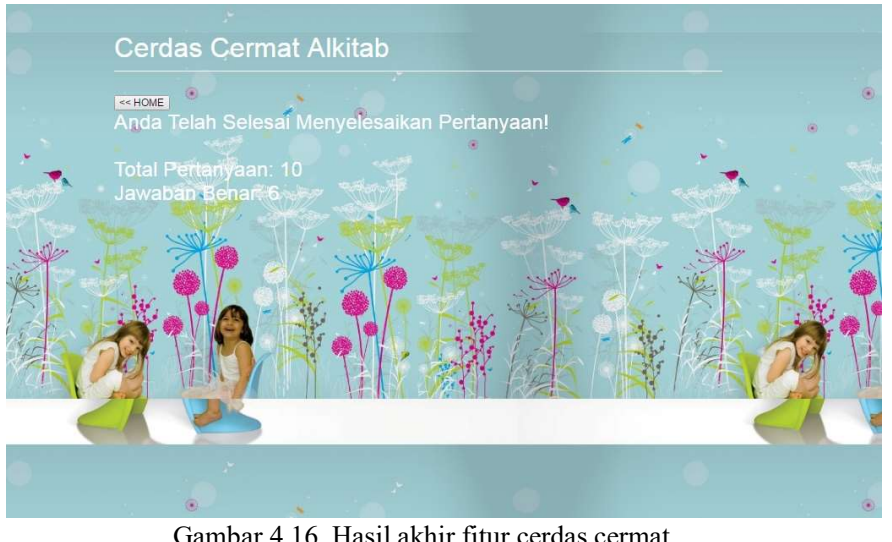

Gambar 4.16. Hasil akhir fitur cerdas cermat

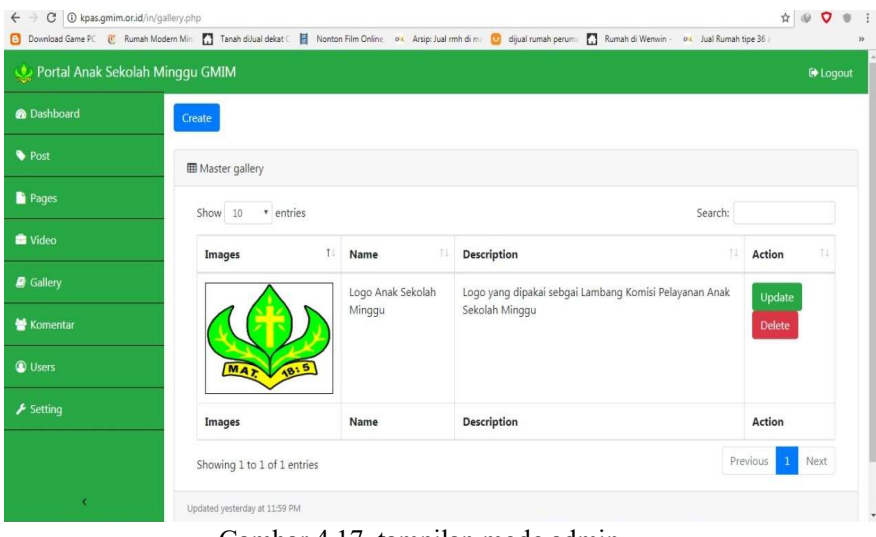

Gambar 4.17. tampilan mode admin

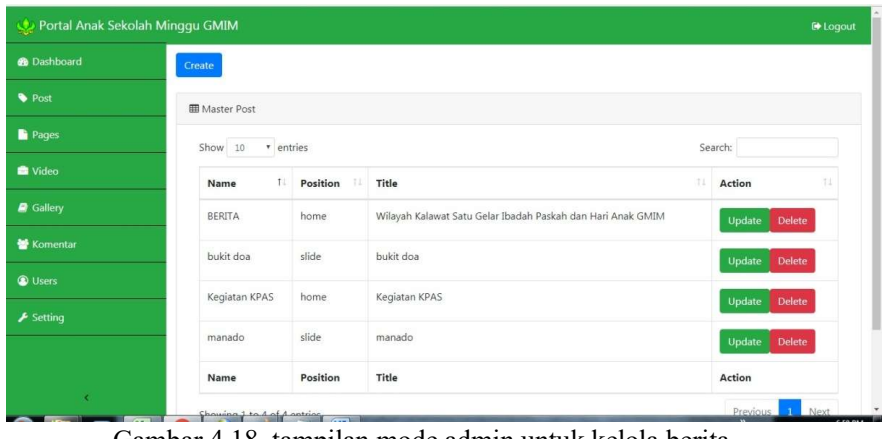

Gambar 4.18. tampilan mode admin untuk kelola berita

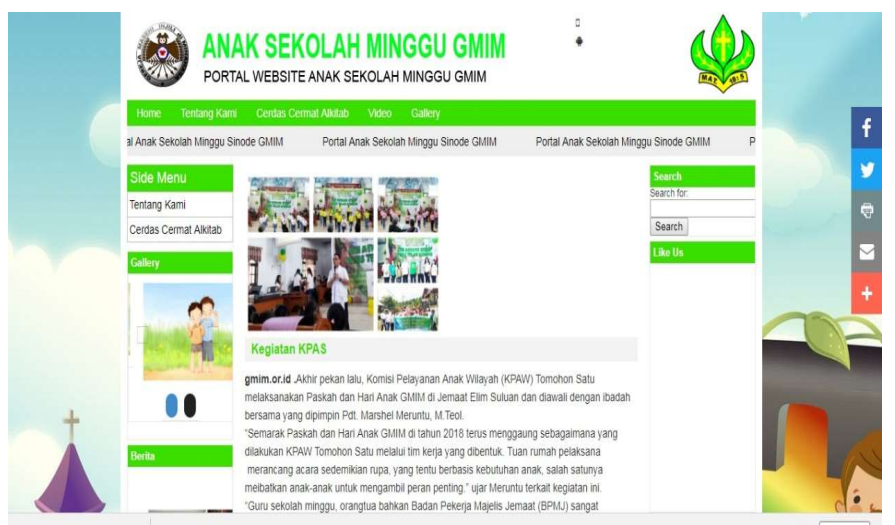

Gambar 4.19. tampilan berita 
Gambar 4.15. adalah tampilan fitur cerdas cermat. Cerdas cermat adalah fitur menjawab pertanyaan.Fitur ini memanfaatkan bahasa pemrograman html dengan menampilakan teks pertanyaan beserta dengan pilihan jawaban. Pengguna dapat melihat pertanyaan dan memilih jawaban kemudian sistem akan menampilkan jawaban benar atau salah, setelah itu sistem akan menampikan pertanyaan selanjutnya. Total soal ada 10 pertanyaan. Setelah menjawab kesepuluh pertanyaan sistem akan menghitung jumlah benar seperti pada gambar 4.16.

Gambar 4.17 adalah tampilan pada mode admin. Dapat dilihat bahwa pada mode admin terdapat beberapa pilihan menu untuk megatur isi konten dalam sistem . Sedangkan gambar 4.18. adalah tampilan mode admin untuk fitur berita. Berita yang akan di tampilkan di atur dalam menu ini dan di tampilkan pada sistem seperti pada gambar 4.19.

\section{Testing/Pengujian}

Tahap ini bertujuan untuk menguji performansi sistem yang telah dibangun dan untuk memastikan semua kebutuhan pengguna dan sistem telah terpenuhi.Pengujian dilakukan setelah hosting .Alamat untuk portal web anak sekolah minggu gmim adalah http://www.kpas.gmim.or.id//.dari hasil pengujian semua menu dapat ditampikan sementara sistem berjalan baik.

\section{KESIMPULAN DAN SARAN}

\section{A. Kesimpulan}

Berdasarkan penelitian yang telah dilakukan dalam membagun portal web anak sekolah minggu sinode GMIM, dapat ditark kesimpulan antara lain :

1. Dari hasil wawancara yang telah dilakukan, dibutuhkan media yang bisa menjadi portal informasi dan alat peraga bagi guru dan anak sekolah minggu.

2. Portal web anak sekolah minggu sinode GMIM merupakan jawaban yang tepat atas kendala yang sering terjadi didalam Komisi pelayanan anak sinode GMIM (KPAS GMIM), diantaranya, keterlambatan informasi, dan kekurangan bahan ajar (alat peraga)

3. Portal web anak sekolah minggu GMIM merupakan sebuah media pembelajaran yang baik bagi anak sekolah minggu karena di bangun menjadi sebuah sistem yang sederhana tetapi sangat menarik untuk anak anak

4. Berdasarkan hasil pengujian fungsi, portal web ini dapat menjalankan fitur fitur yang di butuhkan KPAS untuk menanggulangi masalah masalah yang telah disebutkan sebelumnya.

\section{B. Saran}

Berdasarkan hasil penelitian dan kesimpulan mengenai portal web anak sekolah minggu sinode GMIM, maka diajukan saran sebagai berikut:

Portal web anak sekolah minggu Sinode GMIM harrusnya jadi media penyampaian informasi yang cepat dan tepat, dan menjadi media repository bahan ajar guna. Konten -Konten pada Portal ini seharusnya selalu di Update untuk lebih menambah ketertarikan anak dan guru sekolah minggu kepada sistem ini.

\section{DAFTAR PUSTAKA}

[1] Pressman, Roger S. (2010). Software Engineering : A Practitioner's Approach, Seventh Edition. McGraw Hill Higher Education.

[2] Mamangkey Julita. Sinsuw Alicia. Karouw Stanley. Tuturoong Nancy (2013).Jurnal Informatika;Aplikasi E visual aid berbasis android. Sam Ratulangi University Manado.

[3] Adelin Fatmariani (2014). Jurnal Teknologi Dan Informatika tentang Web Portal Jurnal Ilmiah Online Kopertis Wilayah II Palembang.STMIK PalComTech .Palembang.

[4] Feiby Marlin Pongoh(1), Alicia A. E. Sinsuw(2), Virginia Tulenan(3) (2016). E-Journal Teknik Informatika Vol.8, No.1 Tentang Alat peraga digital pengenalan pahlawan Sulawesi Utara. Universitas Sam Ratulangi Manado.

[5] Fransiskus Lesomar(1), Hans Wowor(2), Virginia Tulenan (3) (2015). E-Journal Teknik Informatika Vol.6, No.1 tentang Rancang bangun Portal Web Pariwisata Maluku Utara. Universitas Sam Ratulangi Manado.

[6] Frederick Constantianus, Bernard Renaldy Suteja(2014). Jurnal Informatika tentang Analisa dan Desain Sistem Bimbingan Tugas Akhir Berbasis Web dengan Studi Kasus Fakultas Teknologi Informasi.Universitas Kristen Maranatha Bandung.

[7] Gilang Ramadhan (2012).Papper tentang Analisis Portal Web Pada Universitas Indonusa Esa Unggul Jakarta.Universitas Bina Dharma

[8] Sinode GMIM (2007). Adendum Tata Gereja GMIM Tahun 2007. Sinode GMIM. SULUT.

[9] Komisi Pelayanan anak sinode GMIM (2014).https://www.gmim.or.id/komisi-pelayanan-anak-anak. (Januari 2016).

[10] Pengertian Web (2012).

http://raghibnuruddin217.blogspot.com/(20,Januari,2015)

[11] Apa itu multimedia?(2013)." Definisi multimedia menurut para ahli" http://www.satriamultimedia.com/artikel_apa_itu_multimedia. html (20, Januari, 2015)

[12] Stanley Karouw(1), Benny Narasiang(2) (2016), EJournal Teknik Informatika tentang Pengembangan Portal Anak Sekolah Minggu Sebagai Bagian Dari Sistem Informasi Terpadu Gereja Masehi Injili Di Minahasa. Universitas Sam Ratulangi Manado. 
[13] Sheila C. Riady(1), Steven Sentinuwu(2), Stanley Karouw (3) (2016). E-Journal Teknik Informatika Vol.9, No.1 tentang Rancang Bangun Aplikasi Mobile LearningAnak Sekolah Minggu dengan Teknologi Augmented Reality Berbasis Android. Universitas Sam Ratulangi Manado.

[14] Membaca Artikel (2012) "PHP Menurut Para Ahli”.http://www.membacaartikel.tk/2016/02/pengertianhtml-menurut-ahli.html. ( 8 November 2016).

[15] Software Proses(2012).

http://stanlysk.blogspot.com/2012/07/software-process.html (20,Januari, 2012).

[16] XAMPP

(2015).https://www.apachefriends.org/

(20,Januari,2012).

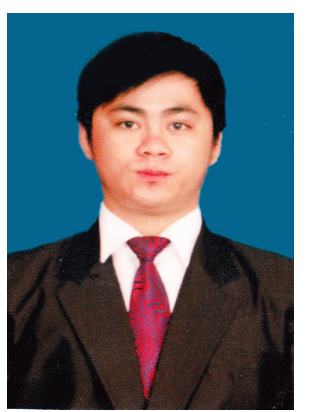

Sekilas dari penulis dengan Nama lengkap Jofny Kevin Wonte. Anak sulung dari pasangan suami isteri Joppy Josef Wonte, Sip. dan Sartje Vonny Rama. Lahir di Kota Manado, Provinsi Sulawesi Utara pada tanggal 11 Maret 1992. Dengan alamat tempat tinggal sekarang di Kelurahan Winangun dua, Kecamatan Malalayang, Kota Manado. Mulai menempuh pendidikan di Seolah Dasar Negeri 71 Manado setelah itu melanjutkan pendidikan di Sekolah Menengah tingkat Pertama Negeri 4 Manado. Selanjutnya menempuh pendidikan Ke Sekolah Menengah Atas Negeri 9 Manado dan selesai studi SMA pada tahun 2009. Masuk keperguruan tinggi negeri di kota Manado pada tahun 2011 yaitu Universitas Sam Ratulangi, dengan mengambil Program Studi S-1 Teknik Informatika di Jurusan Elektro, Fakultas Teknik. Penulis membuat Penelitian demi memenuhi syarat memperoleh gelar S1 Sarjana Komputer dengan penelitian berjudul Portal Web Anaks Sekolah Minggu Sinode GMIM, yang dibimbing oleh dua dosen pembimbing yaitu Alicia Sinsuw, ST., MT. dan Stanley D.S. Karouw, ST., MTI pada tanggal 23 Agustus 2018 penulis selesai melaksanakan pendidikan di Fakultas Teknik Universitas Sam Ratulangi, Jurusan Teknik Elektro, Progam Studi Teknik Informatika sehingga menyandang gelar sebagai Sarjana Komputer (S.Kom) dan lulus dengan predikat memuaskan. 